\title{
A Case of Lens Subluxation in Exfoliative Glaucoma
}

\author{
Suci Permata Sari ${ }^{1}$, Andrini Ariesti ${ }^{2}$
}

\begin{abstract}
Abstrak
Glaukoma eksfoliasi dengan luksasi lensa ke posterior pada satu mata dan subluksasi lensa ke anterior pada mata yang lain dengan tanda dan gejala glaukoma akut. Dilaporkan seorang pria berusia 54 tahun datang ke Rumah Sakit Dr M Djamil Padang dengan keluhan utama penglihatan mata kiri kabur dan merah sejak 15 hari yang lalu dan penglihatan mata kanan kabur sejak 6 bulan yang lalu. Tidak ada riwayat trauma dan operasi pada kedua mata. Tajam penglihatan mata kanan 1/60 dan mata kiri 1/300. Pemeriksaan status oftalmologi mata kanan, kedalaman Kamera Okuli Anterior (KOA) didapatkan VH4 dan lensa luksasi ke posterior. Pemeriksaan status oftalmologi mata kiri ditemukan tanda dan gejala glaucoma akut. Tekanan intra ocular mata kanan $32 \mathrm{mmHg}$ dan mata kiri $50 \mathrm{mmHg}$. Pemeriksaan funduskopi pada mata kanan terlihat lensa di retina inferior. Pasien direncanakan untuk ekstraksi lensa dan implantasi Intraocular lens (IOL) intra operatif ketika pupil dalam keadaan dilatasi terlihat white dandruff like flakes di permukaan lensa anterior dan lensa subluksasi ke anterior, sehingga pada pasien ini diputuskan untuk dilakukan intra capsular cataract extraction. Sebagian besar glaukoma eksfoliasi onsetnya lambat, namun pada kasus ini tanda dan gejala glaukoma akut disebabkan oleh subluksasi lensa ke anterior.
\end{abstract}

Kata kunci: sindroma eksfoliasi, glaukoma eksfoliasi, subluksasi lensa, luksasi lensa

\begin{abstract}
A exfoliative glaucoma with lens luxation to posterior in one eye and lens subluxation to anterior in the other eye with acute glaucoma signs and symptoms. Reported a fiftyfour yo male was admitted to Dr M Djamil Hospital Padang with main complain red and blurred vision on the $L E$ since fifteen days ago and blurred vision on the RE since six month ago. No history of trauma and surgery on both eye. VA RE one meter and LE hand movements. In RE the AC was VH4 and the lens luxation to posterior. In LE we saw acute glaucoma signs and symptoms. IOP in RE was thirty two $\mathrm{mmHg}$ and fifty $\mathrm{mmHg}$ in LE. Funduscopy in RE we saw lens in inferior retina. Patient was plan for ECCE and IOL implantation OS. Intra operatif when pupillary dilatation we saw a white, dandruff-like flakes on anterior lens surface and the lens was subluxation to anterior, so we decided to do ICCE for this patient. Conclusion: Most of the exfoliative glaucoma were late onset, but in this case we found acute glaucoma signs and symptoms induced by lens subluxation to anterior.
\end{abstract}

Keywords: exfoliation syndrome, exfoliating glaucoma, lens subluxation, lens luxation

Affiliasi penulis: 1. Dinas Kesehatan Kabupaten Dharmasraya, 2. Bagian IImu Kesehatan Mata Fakultas Kedokteran Universitas Andalas Padang.

Korespondensi: Suci Permata Sari, buncillindol@gmail.com Telp: 08116627773

\section{PENDAHULUAN}

Sindroma eksfoliasi sebelumnya dikenal sebagai sindroma pseudoeksfoliasi, terjadi ketika beberapa jaringan okular mensintesis protein yang abnormal. Protein ini akan menyumbat trabekular meshwork dan menyebabkan glaukoma eksfoliasi. Sindroma eksfoliasi yang terkait glaukoma dikenal dengan berbagai macam nama, yaitu pseudoeksfoliasi, senile eksfoliasi, senile uveal eksfoliasi, glaukoma kapsular dan iridociliary eksfoliasi. Sindroma eksfoliasi lebih sering pada wanita daripada laki-laki, namun kombinasi sindroma eksfoliasi dan glaukoma eksfoliasi terjadi sama pada kedua jenis kelamin. Sindroma eksfoliasi ini sangat kuat kaitannya dengan usia, sehingga sindroma ini 
jarang terlihat pada pasien dengan usia dibawah 50 tahun dan paling sering terjadi pada pasien usia diatas 70 tahun. $^{1,2}$

Sindroma eksfoliasi ditandai dengan berkembangnya whitish granular dan dandruff like flakes di lensa, pinggir pupil dan segmen anterior lainnya. Sindroma eksfoliasi merupakan gangguan metabolisme di dalam mata yang dapat menyebabkan glaukoma eksfoliasi dan merupakan bentuk paling berat dari glaukoma sudut terbuka sekunder. ${ }^{3,4}$

Sindroma eksfoliasi terkait dengan glaukoma, pertama kali di dideskripsikan oleh Lindberg di Finlandia pada tahun 1917. Peningkatan tekanan intraokular pada glaukoma eksfoliasi biasanya jelas terlihat, sulit dikontrol dengan obat-obatan dan sering memerlukan intervensi bedah. ${ }^{5,6}$

Prevalensi sindroma eksfoliasi terus meningkat dengan bertambahnya usia pada semua populasi. Sekitar dua pertiga pasien secara klinis memiliki keterlibatan unilateral. Resiko berkembangnya glaukoma adalah kumulatif dari waktu ke waktu. Sekitar 25\% pasien dengan sindroma eksfoliasi mempunyai tekanan intra okular tinggi dan 1/3 berkembang menjadi glaukoma eksfoliasi. ${ }^{7}$

\section{KASUS}

Seorang pria berusia 54 tahun datang ke Rumah Sakit dr. M. Djamil Padang dengan keluhan utama penglihatan mata kiri kabur dan merah sejak 15 hari yang lalu dan penglihatan mata kanan kabur sejak 6 bulan yang lalu. Sebelumnya pasien berobat ke spesialis mata di rumah sakit umum daerah diberi obat tetes mata dan obat makan (timol ed 0,5\%, cenfresh ed, glaucon tab dan Aspar K) namun karena tidak ada perbaikan pasien dirujuk ke RSdr.M. Djamil Padang. Riwayat mata kiri merah dan sakit kepala sejak 15 hari yang lalu. Tidak ada riwayat trauma dan operasi pada kedua mata. Riwayat menderita diabetes dan hipertensi disangkal. Riwayat mata kanan merah dan disertai rasa sakit sebelumnya disangkal.

Dilakukan pemeriksaan oftalmologi dan didapatkan tajam penglihatan mata kanan 1/60 dan mata kiri 1/300. Pemeriksaan status oftalmologi mata kanan, kedalaman COA didapatkan VH4 dan lensa luksasi ke posterior. Pemeriksaan status oftalmologi mata kiri ditemukan tanda dan gejala glaucoma akut. Tekanan intra ocular mata kanan $32 \mathrm{mmHg}$ dan mata kiri $50 \mathrm{mmHg}$.
OD

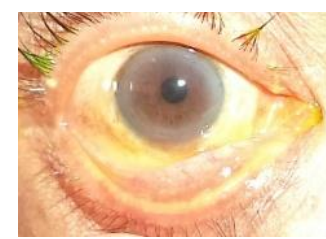

OS

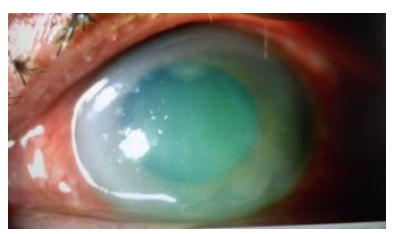

Gambar 1. Hasil inspeksi mata pasien

Pemeriksaan funduskopi pada mata kanan terlihat lensa di retina inferior. Pemeriksaan gonioskopi pada mata kanan ditemukan kesan sudut terbuka, kemudian dilakukan pemeriksaan USG tampak lensa di retina inferior. Pasien didiagnosis dengan glaukoma fakomorfik mata kiri, katarak imatur mata kiri, afakia ec luksasi lensa mata kanan ke posterior. Diagnosis banding adalah glaukoma eksfoliasi ODS. Pasien dilakukan pemeriksaan laboratorium dan dikonsulkan ke Bagian Penyakit Dalam dan didiagnosis sebagai hipertensi stage II essensial dan polisitemia vera.

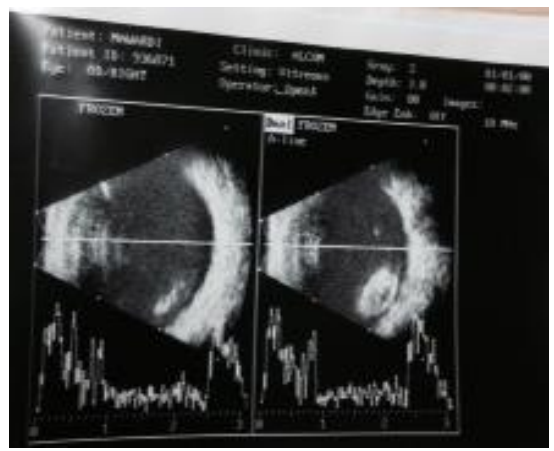

Gambar 2. Hasil pemeriksaan USG

Pasien diterapi dengan glaucon tab $4 \times 250 \mathrm{mg}$, Aspar $\mathrm{K}$ tab $3 \times 1$, Timol $0,5 \%$ ed $2 \times 1$ ODS, polydex ed 6x1 OS dan pasien direncanakan untuk ekstraksi lensa dan implantasi IOL dalam local anestesi. Intra operatif ketika pupil dalam keadaan dilatasi terlihat white dandruff like flakes di permukaan lensa anterior dan lensa subluksasi ke anterior, sehingga pada pasien ini diputuskan untuk dilakukan intra capsular cataract extraction. 


\section{PEMBAHASAN}

Dilaporkan kasus glaukoma eksfoliasi dengan luksasi lensa ke posterior pada mata kanan dan subluksasi lensa ke anterior pada mata kiri pasien lakilaki usia 54 tahun. Berdasarkan anamnesis didapatkan bahwa penglihatan mata kiri kabur dan nyeri sejak \pm 15 hari yang lalu. Riwayat mata kiri merah dan riwayat sakit kepala (+) sejak \pm 15 hari yang lalu. Penglihatan mata kanan kabur sejak 6 bulan yang lalu. Riwayat trauma pada kedua mata disangkal. Riwayat operasi pada mata kanan sebelumnya disangkal. Riwayat diabetes melitus disangkal. Riwayat hipertensi disangkal. Riwayat mata kanan merah dan disertai rasa sakit sebelumnya disangkal. Berdasarkan pemeriksaan oftalmologi visus pada mata kanan adalah 1/60 dan mata kiri 1/300. Pada mata kiri ditemukan tanda-tanda glaukoma akut dan lensa keruh (intumescen). Tekanan intra okular (TIO) mata kanan $32 \mathrm{mmHg}$ dan mata kiri $50 \mathrm{mmHg}$. Dari pemeriksaan funduskopi indirect dan USG mata kanan terlihat lensa di inferior retina.

Awalnya pasien didiagnosis sebagai glaukoma fakomorfik OS, karena penyempitan sudut berhubungan dengan efek massa yang diperoleh dari lensa katarak. Penyempitan sudut pada umumnya terjadi berlahan-lahan seiring dengan munculnya katarak, namun pada beberapa kasus onsetnya bisa akut dan cepat, dipicu oleh pembengkakan dari lensa. Terapi definitif pada glaukoma fakomorfik ini adalah ekstraksi lensa, sehingga pada pasien ini direncanakan ECCE dan implantasi IOL mata kiri. ${ }^{8}$

Pemeriksaan oftalmologis pada mata kanan didapatkan iris trimulans atau iridodonesis (+), lensa luksasi ke posterior dan terdapat peningkatan tekanan intra okular $32 \mathrm{mmHg}$, sehingga mata kanan didiagnosis glaukoma sekunder OD ec luksasi lensa ke posterior. Blok pupil bisa terjadi pada mata afakia dan pseudofakia, yang disebabkan karena permukaan vitreus yang intak bisa memblok pupil. Umumnya COA dangkal dan terlihat gambaran iris bombe. ${ }^{8}$

Pasien ini di diterapi dengan Glaucon tab $4 x$ $250 \mathrm{mg}$, Aspar K tab $3 \times 300 \mathrm{mg}$, Timol ed 0,5\% 2x1 ODS dan Polydex ed $6 \times 1$ OS. Pasien ini diterapi dengan terapi maksimal untuk menurunkan tekanan intra okular pada mata kanan dan kiri, sebelum melakukan tindakan operasi pada mata kiri. Pasien ini juga diberikan kortikosteroid untuk mengkontrol inflamasi yang timbul akibat serangan glaukoma akut. Terapi ini sesuai dengan tiga prinsip dasar dari penatalaksanaan acute angle closure yaitu menurunkan TIO dengan cepat dan mengontrol TIO dan inflamasi, modifikasi sudut untuk mengkoreksi blok mekanik, terapi definitif untuk menjaga TIO tetap terkontrol dan mencegah rekurensi. ${ }^{9}$

Pasien ini dikonsulkan ke sub bagian vitreo retina. Di sub bagian vitreo retina dilakukan funduskopi indirek dan USG untuk menilai segmen posterior. Dari funduskopi indirek dan USG terlihat lensa utuh di retina inferior dan retina intak. Dari sub bagian vitreo retina dianjurkan untuk dilakukan vitrektomi OD.

Pasien juga dikonsulkan ke Bagian Penyakit Dalam karena tekanan darah yang tinggi yaitu 190/100 $\mathrm{mmHg}$ dan hasil laboratorium terdapat peningkatan haemoglobin, eritrosit, hematokrit dan leukosit. Pasien ini didiagnosis dengan hipertensi stage II essensial dan polisitemia vera. Pasien ini didiagnosis banding dengan polisitemia sekunder.

Polisitemia adalah peningkatan jumlah eritrosit, konsentrasi hemoglobin darah dan hematokrit. Polisitemia merupakan akibat sekunder dari berbagai kondisi yang menyebabkan hipoksemia kronis atau meningkatnya produksi eritropoetin. ${ }^{10}$

Polisitemia vera merupakan kelainan pada sistem mieloproliferatif yang melibatkan unsur-unsur hemopoetik dalam sumsum tulang dimana mulainya diam-diam tetapi kronik progresif serta sering dikaitkan dengan leukositosis dan trombositosis.. Hal ini terjadi karena sebagian populasi eritrosit berasal dari satu klon stem cells darah yang abnormal. Polisitemia vera biasanya mengenai pasien berumur 40-60 tahun, rasio perbandingan antara pria dan wanita 2:1 dan dilaporkan insiden polisitemia vera adalah 2,3 per 100.000 populasi dalam setahun. ${ }^{10,11}$

Manifestasi okular pada polisitemia biasanya akibat dari trombosis atau hiperviskositas. Manifestasi okular pada polisitemia yaitu atropi nervus optikus, papiledema dan CRVO. Pada polisitemia dengan derajat yang lebih ringan mungkin ditemukan perubahan fundus seperti tortuositas vena, nervus optikus hiperemis dan mikroaneurisma. ${ }^{11}$ 
Extracapsular Cataract Extractraction (ECCE) dan ekstraksi lensa pada pasien ini dilakukan pada hari kelima rawatan. Hal ini disebabkan karena tekanan darah pasien yang tinggi, peningkatan haemoglobin, eritrosit, hematokrit dan leukosit. Pada hari kelima tekanan intra okular mata kiri pasien 43,4 $\mathrm{mmHg}$, sehingga pre operatif diberikan infus manitol $20 \%$ dengan dosis 1-2 gr/KgBB. Setelah 15 menit pertama pemberian manitol TIO pasien turun mejadi $33 \mathrm{mmHg}$, setelah 15 menit kedua TIO turun menjadi $26,6 \mathrm{mmHg}^{12}$

Intra operatif pada saat pupil dalam keadaan dilatasi maksimal, tekanan intra okular turun dan Camera Okuli Anterior cukup dalam, terlihat lensa mata kiri subluksasi lebih dari dua kuadran ke anterior dan terlihat deposit material putih di permukaan kapsul lensa anterior sehingga kemudian pasien didiagnosa dengan glaukoma eksfoliasi dan diputuskan untuk melakukan operasi dalam dua tahap, dimana tahap pertama dilakukan ekstraksi lensa (ICCE OS) dan kemudian tahap kedua dilakukan operasi trabekulektomi.

Glaukoma eksfoliasi adalah manifestasi okular yang sangat penting dari sindroma eksfoliasi. Glaukoma eksfoliasi sering muncul secara diam-diam, unilateral dan sering terdiagnosis ketika sudah parah. Sindroma eksfoliasi adalah kondisi sistemik terkait umur yang ditandai dengan produksi dan akumulasi material ekstraseluler fibril yang abnormal. Material gray-white flaky, deposit di seluruh jaringan segmen anterior mata, menutupi zonula dan prosesus siliaris, di dinding arteri siliaris posterior, vortex vein, pembuluh darah retina sentralis serta di seluruh tubuh manusia. $^{13,14}$

Sindroma eksfoliasi tidak hanya menyebabkan glaukoma sudut terbuka kronik yang berat, glaukoma sudut tertutup terkait dengan subluksasi lensa, gangguan blood aqueous barrier dan komplikasi serius saat ekstraksi katarak yaitu dilatasi pupil yang jelek, ruptur zonule, robeknya kapsul, kehilangan vitreus dan komplikasi post operatif seperti sinekia posterior dan deposit sel. Pada mata kiri pasien ini glaukoma eksfoliasi muncul dengan gambaran glaukoma akut yang terkait dengan subluksasi lensa karena kelemahan zonula. ${ }^{15,16}$
Sindroma eksfoliasi telah lama dikaitkan dengan resiko berkembangnya katarak. Pada tahun 1917, Lindberg melaporkan hubungan antara sindroma eksfoliasi dengan katarak. Beberapa penelitian lainnya menunjukkan bahwa peningkatan kekeruhan lensa dikaitkan dengan sindroma eksfoliasi, namun kondisi ini juga terkait dengan usia. ${ }^{14}$

Puska dan Tarkkanen pada tahun 2001, melakukan penelitian prospektif selama 5 tahun pada 63 pasien nonglaukomatous dengan gambaran klinis sindroma eksfoliasi unilateral. Pada penelitian ini kedua mata pasien dinilai tajam penglihatan, status refraksi dan perkembangan kekeruhan lensa menggunakan Lens Opacity Meter dan didapatkan bahwa sindroma eksfoliasi berhubungan dengan peningkatan kekeruhan lensa. ${ }^{15}$

Mata dengan sindroma eksfoliasi memerlukan operasi terkait dengan katarak dan terkait dengan peningkatan tekanan intra okular dibandingkan mata tanpa sindroma eksfoliasi. Operasi kombinasi katarak dan glaukoma merupakan pengobatan yang efektif untuk pasien dengan glaukoma eksfoliasi. Sesuai dengan penelitian yang dilakukan oleh Shingleton et al pada tahun $2011 .^{14}$

Fakoemulsifikasi menjadi gold standar pada operasi katarak pasien dengan sindroma eksfoliasi. Beberapa penelitian memperlihatkan insiden komplikasi yang tinggi dengan ECCE pada mata dengan sindroma eksfoliasi, dimana sering terjadinya ruptur kapsul posterior dan kehilangan vitreus. ${ }^{17}$

Glaukoma eksfoliasi lebih progresif, mempunyai prognosis yang buruk dan merupakan faktor resiko yang potensial untuk berkembangnya kerusakan nervus optikus glaukomatous dibandingkan glaukoma primer sudut terbuka. Penelitian yang pernah dilakukan oleh Kim et al pada tahun 2013 mengevaluasi gambaran lamina kribrosa pada pasien dengan glaukoma eksfoliasi menggunakan enhanced depth imaging dari spectral domain optical coherence tomography. Hasilnya dibandingkan dengan pasien glaukoma sudut terbuka primer dengan tingkat keparahan glaukoma yang sama dan didapatkan hasil dimana mata dengan glaukoma eksfoliasi memperlihatkan lamina kribrosa yang lebih tipis dibanding glaukoma sudut terbuka primer. ${ }^{18}$ 
Glaukoma eksfoliasi memiliki perjalanan klinis yang lebih serius daripada glaukoma sudut terbuka primer. Rata-rata TIO lebih besar pada pasien glaukoma eksfoliasi daripada pasien glaukoma sudut terbuka primer. Fluktuasi tekanan intra okular pada pasien dengan sindroma eksfoliasi pada pengukuran diurnal lebih besar dibandingkan dengan glaukoma sudut terbuka primer. Peningkatan tekanan kronis pada mata dengan sindroma eksfoliasi disebabkan oleh peningkatan resistensi aliran keluar di trabekular meshwork, karena penyumbatan aliran akuous oleh material eksfoliasi. $^{5}$

Pembentukan bertahap dari material eksfoliasi berkorelasi dengan level peningkatan tekanan intra okular dan munculnya kerusakan nervus optikus glaucomatous yang berat. Material eksfoliasi diproduksi secara lokal oleh sel-sel endotel yang melapisi kanal schlemm. Deposit material eksfoliasi dapat ditemukan di seluruh trabekular meshwork, namun efek utamanya terletak pada akumulasi di jaringan juxtacanalicular di bagian bawah dinding kanal schlemm, yang merupakan bagian resistensi yang besar dari aliran akuous dan menyebabkan perubahan degeneratif yang progresif dari kanal schlemm, termasuk penyempitan, fragmentasi, penebalan dan obstruksi pada kasus yang lebih lanjut. Hal ini menunjukkan adanya hubungan langsung antara penumpukan material eksfoliasi di trabekular meshwork dengan perkembangan dan progresifitas glaukoma, dan disarankan upaya terapi adalah meningkatkan aliran keluar untuk mengatasi perubahan di daerah juxtacanalicular dan untuk mendapatkan penurunan tekanan intra okular. ${ }^{5}$

Pasien ini didiagnosis dengan glaukoma eksfoliasi karena ditemukannya material eksfoliasi yang khas pada permukaan lensa anterior mata kiri, namun tidak terlihat tanda material eksfoliasi pada mata kanan. Sindroma eksfoliasi ini secara klinis seringkali tampak hanya pada satu mata atau unilateral, namun kondisi sebenarnya bisa bilateral dengan gambaran yang sangat asimetris dikedua mata. Beberapa penelitian mengatakan bahwa pasien dengan sindroma eksfoliasi unilateral akan mendapatkan gambaran klinis pada mata sebelahnya setelah 5-10 tahun. ${ }^{7}$

Deposit material putih di permukaan lensa anterior adalah gambaran diagnostik yang paling penting dan merupakan gambaran yang paling umum dari sindroma eksfoliasi seperti yang terlihat pada Gambar 1. Ada tiga zona yang berbeda pada permukaan lensa anterior yang merupakan ciri khas dari sindroma eksfoliasi yaitu: translucent central zone, granular peripheral zone dan clear zone. ${ }^{19}$

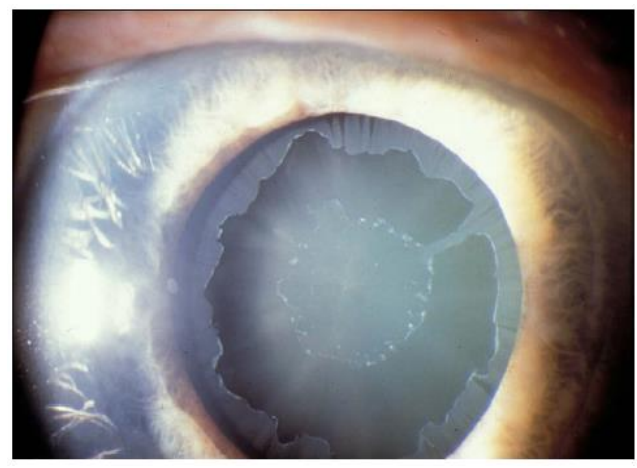

Gambar 3. Deposit material eksfoliasi di kapsul lensa anterior ${ }^{13}$

Material eksfoliasi juga sering ditemukan di pinggir pupil seperti yang terlihat pada Gambar 2. Sembilan puluh empat persen pasien dengan sindroma eksfoliasi didiagnosa sebelum dilatasi pupil dengan menemukan material eksfoliasi pada pinggir pupil. Pemeriksaan tanda-tanda halus dari sindroma eksfoliasi sering terabaikan yang sangat berguna untuk diagnosa. Tanda ini termasuk defek di pupillary ruff, transiluminasi sfingter iris, deposit pigmen yang karakteristik pada sfingter iris dan deposit pigmen di permukaan anterior iris dan trabekular meshwork. Tanda-tanda ini bisa asimetris dan berfungsi sebagai petunjuk untuk diagnosa. Defek pada pupillary ruff paling sering dan meningkat dengan usia. Pada kasus sindroma eksfoliasi unilateral, defek pada pupillary ruff terjadi dua kali lebih sering pada mata yang terkena. Selain itu, defek juga terjadi $82 \%$ pada mata yang mempunyai material eksfoliasi pada pinggir pupil. ${ }^{19}$ 


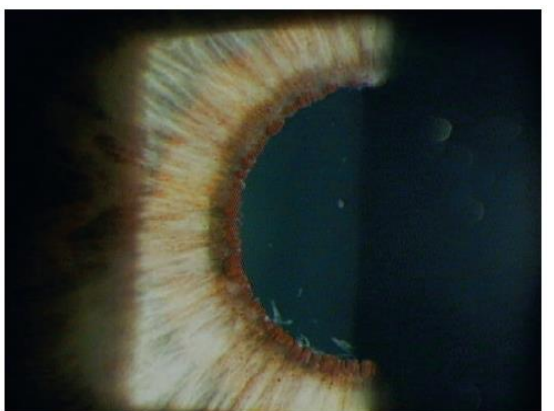

Gambar 4. Material eksfoliasi di pinggir pupil ${ }^{5}$

Sindroma eksfoliasi sering dikaitkan dengan peningkatan pigmen di trabekular meshwork dengan gambaran karakteristik difus, pigmen terdistribusi seperti titik di seluruh sudut, tidak halus dan deposit pigmennya lebih homogen daripada sindroma dispersi pigmen. Sering terlihat garis pigmen di anterior schwalbe line. Derajat dari pigmentasi berkaitan dengan keparahan dari glaukoma. Deposit pigmen dan material eksfoliasi bisa terjadi di endotel, biasanya difus dan pola mungkin seperti Krukenberg spindle. ${ }^{19}$

Glaukoma eksfoliasi cendrung lebih berat daripada glaukoma sudut terbuka primer dengan manifestasi rata-rata tekanan intra okular tinggi, kerusakan nervus optikus yang lebih besar saat diagnosis, dan respon yang buruk terhadap terapi obat-obatan, sering memerlukan intervensi bedah. ${ }^{5}$

Pendekatan umum untuk pasien dengan sindroma eksfoliasi dan glaukoma eksfoliasi mirip dengan pendekatan glaukoma sudut terbuka primer, namun ada perbedaan sehubungan dengan pengobatan dan prognosis. Glaukoma eksfoliasi biasanya muncul dengan tekanan intraokular yang tinggi dan respon terhadap terapi obat-obatan kurang atau lebih resisten terhadap terapi obat-obatan dibandingkan glaukoma sudut terbuka primer. ${ }^{19}$

Post ICCE pasien diterapi dengan timol ed 0,5\% 2x2 OD, azopt ed 3x1 OD, polydex ed $6 \times 1$ OS dan methyl prednisolon $1 \times 16 \mathrm{mg}$. Awalnya terapi glaukoma hanya diberikan untuk mata kanan karena TIO pada mata kanan $24,4 \mathrm{mmHg}$ dan pada mata kiri tidak diberikan terapi glaukoma postt ICCE karena TIO mata kiri norml (palpasi). Setelah satu minggu post ICCE, tekanan mata kanan tetap tinggi yaitu $24 \mathrm{mmHg}$ sehingga terapi azopt ed diganti dengan glaopen ed 1x1 OD. Literatur dikatakan bahwa first line terapi pada glaukoma eksfoliasi ini adalah prostaglandin analog dan akuos supresant, sehingga pasien ini diterapi dengan timol ed $0,5 \% 2 \times 1$ OD dan glaopen ed $1 \times 1$ OD. Kemudian 4 minggu post ICCE tekanan intra okular mata kiri meningkat menjadi $24 \mathrm{mmHg}$ sehingga terapi diberikan pada kedua mata. ${ }^{5}$

Penelitian yang dilakukan Konstas et al pada tahun 2007, dimana mereka mengevaluasi efektivitas latanoprost versus travoprost pada pasien glaukoma eksfoliasi dengan menilai tekanan intra okular selama 24 jam, dan didapatkan hasil bahwa latanoprost dan travoprost secara signifikan mengurangi TIO selama 24 jam dari baseline, namun travoprost memperlihatkan efektivitas yang lebih besar pada sore hari. $^{20}$

Pada enam minggu post ICCE setelah media cukup bening, dilakukan pemeriksaan funduskopi pada mata kiri dan didapatkan papil bulat, batas tegas dan c/d 0,9-1. Hal ini bisa disebabkan karena peningkatan TIO kronis pada glaukoma eksfoliasi, karena penyumbatan material eksfoliasi di TM yang menyebabkan meningkatnya resistensi aliran keluar pada TM, atau disebabkan karena peningkatan TIO akut akibat mekanisme blok pupil karena subluksasi lensa ke anterior. ${ }^{5}$

Pasien sindroma eksfoliasi mengalami aliran darah okular, retrobulbar dan serebral berkurang dengan atau tanpa glaukoma eksfoliasi. Secara klinis pada kasus unilateral, pulsasi ipsilateral aliran darah okular dan aliran darah carotid dilaporkan menurun. Pasien dengan sindroma eksfoliasi mempunyai penurunan yang besar pada kecepatan aliran darah arteri oftalmika, arteri retina sentralis dan arteri siliaris posterior brevis. Aliran darah dari lamina kribrosa dan neural rim menurun sehingga meningkatkan kerusakan glaukomatous. ${ }^{5}$

Prognosis glaukoma pada sindroma eksfoliasi lebih jelek dibandingkan dengan glaukoma sudut terbuka primer, oleh karena itu pasien dengan glaukoma eksfoliasi lebih memerlukan laser trabeculoplasty atau filtering surgery. Argon laser trabeculoplasty memiliki efek penurunan tekanan intra okular terbesar pada glaukoma eksfoliasi. Pasien dengan glaukoma eksfoliasi cendrung lebih baik setelah laser trabeculoplasty. ${ }^{21,22}$ 


\section{SIMPULAN}

Manajemen terapi glaukoma eksfoliasi yaitu terdiri dari penggunaan obat-obatan yang dapat menurunkan tekanan intra okular, laser trabeculoplasty dan trabekulektomi.

\section{SARAN}

Glaukoma eksfoliasi lebih progresif mempunyai prognosis yang buruk dan mempunyai faktor resiko yang potensial untuk berkembangnya kerusakan nervus optikus glaucomatous dibandingkan dengan glaucoma primer sudut terbuka, oleh karena itu diperlukan pemeriksaan menyeluruh dan pengobatan yang komprehensif.

\section{UCAPAN TERIMA KASIH}

Terimakasih kepada Ketua Bagian IImu Kesehatan Mata RSUP dr. M. Djamil Padang, Koordinator Program Studi PPDS IImu Kesehatan Mata FK Unand serta Ketua Subbagian Glaukoma RSUP Dr M Djamil/ FK Unand yang telah membantu kelancaran penulisan artikel ini.

\section{DAFTAR PUSTAKA}

1. Stamper RL. Lieberman MF, Drake MV. BeckerShaffer's diagnosis and therapy of glaucoma. 8th Edisi ke-8. China: Mosby; 2009.hlm.269-70.

2. Skuta GL, Cantor LB, Weiss JS. Glaucoma. San Fransisco: American Academy Of Ophthalmology; 2014-2015.hlm.85-7.

3. Johnson DH. Pseudoexfoliation syndrome and glaucoma. Dalam: Morrison JC, Pollack IP, editor (penyunting). Glaucoma science and practice. New York: Thieme; 2003.hlm. 215-25.

4. Costa VP, Wilson RP, Azuara-Blanco A. Handbook of glaucoma. United Kingdom: Martin Dunitz Ltd; 2002 (diunduh Januari 2018). Tersedia dari: http://www.dunitz.co.uk

5. Ritch R,Schlotzer U, Allingham RR. Exfoliation syndrome and exfoliative glaucoma. Dalam: Shaarawy TM, Sherwood MB, Hitchings RA, Crowston JG, editor (penyunting). Glaucoma medical diagnosis and therapy. Edisi ke-2. London: Elsevier; 2015.hIm. 357-65.
6. Skuta GL, Morgan RK. Exfoliation syndrome, pigment dispersion syndrome and the associated glaucomas. Dalam: Tasman W, Jaeger EA, editor (penyunting). Duane's ophthalmology. Lippincott Williams and Wilkins; 2013.hlm.1-30.

7. Sit AJ, Johnson DH. The exfoliation syndrome: a continuing challenge. Dalam: Albert M, Miller JW, editor (penyunting). Principles and practice of ophthalmology. Edisi ke-3. London: Elsevier; 2008. hlm. 2581-93.

8. Skuta GL, Cantor LB, Weiss JS. Glaucoma. San Fransisco: American Academy Of Ophthalmology; 2014-2015.hlm.109-37.

9. Ritch $R$, Schlotzer $U$, Allingham RR. Acute Intraocular Pressure. Dalam: Shaarawy TM, Sherwood MB, Hitchings RA, Crowston JG, editor (penyunting). Glaucoma medical diagnosis and therapy. Edisi ke-2. London: Elsevier; 2015. hlm. 600-8.

10. Kaiser RS, Williams GA. Ocular manifestations of hematologic diseases. Dalam: Tasman W, Jaeger EA. Editor (penyunting). Duane's ophthalmology. Lippincott Williams and Wilkins; 2013.hlm.1-29.

11. Prenggono MD. Polisitemia vera. Dalam: Sudoyo AW, Setiyohadi B, Alwi I, Simadibrata M, Setiati S, editor (penyunting). Buku ajar ilmu penyakit dalam volume II. Edisi ke-4. Jakarta: IPD FKUI; 2006.hIm. 702-5.

12. Skuta GL, Cantor LB, Weiss JS. Glaucoma. San Fransisco: American Academy Of Ophthalmology; 2014-2015.hlm.170-89.

13. Riedel PJ, Samuelson TW. Pseudoexfoliative glaucoma. Dalam: Yanoff M, Duker JS, editor (penyunting). Ophthalmology. Edisi ke-3. China: Elsevier; 2009.hlm.1172-4.

14. Shingleton BJ, Wooler KB, Bourne Cl. Combined cataract and trabeculectomy surgery in eyes with pseudoexfoliation glaucoma. Journal Cataract Refractive Surgery. 2011;37:1961-70.

15. Puska P, Trakkanen A. Exfoliation syndrome as a risk factor for cataract development. Journal Cataract Refractive Surgery. 2001;27:1992-8.

16. Lumme $P$, Laatikainen L. Exfoliation syndrome and cataract extraction. American Journal of Ophthalmology. 1993;116:51-5. 
17. Konstas AGP, Ziakas NG, Teus MA. Cataract surgery in patient with exfoliation syndrome. Dalam: Johnson S, editor (penyunting). Cataract surgery in the glaucoma patient. USA: Springer; 2009.hlm.161-76.

18. Kim S, Sung KR, Lee JR. Evaluation of lamina cribrosa in pseudoexfoliation syndrome using spectral-domain optical coherence tomography enhanced depth imaging. American Academy of Ophthalmology Journal. 2013;120:1798-803.

19. Prince AM, Ritch R. Clinical signs of the pseudoexfoliation syndrome. Journal of Ophthalmology. 1986;93:803-7.
20. Konstas AGP, Kozobolis VP, Katsimpris IE. Efficacy and Safety of Latanoprost versus travoprost in exfoliative glaucoma patients. American Academy of Ophthalmology Journal. 2007;114:653-7.

21. Ritch R. Directed therapy for specific glaucomas. Opthalmology Clinics of North America. 2000;13: 429-41.

22. Konstas AGP, Jay JL, Marshall GE. Prevalence, diagnostic features, and response to trabeculectomy in exfoliation glaucoma. Journal of Ophthalmology. 1993;100: 619-27. 